\title{
The United States Naval Academy's Center for Middle East and Islamic Studies
}

\author{
Brannon Wheeler
}

\begin{abstract}
In August 2005, the Center for Middle East and Islamic Studies was established at the United States Naval Academy in Annapolis, Maryland. This was the result of a multi-year review of the academy's curriculum as part of far-reaching efforts under Admiral Rodney Rempt, the current superintendent, to provide a more international and interdisciplinary curriculum to the students.
\end{abstract}

\section{The United States Naval Academy}

Founded in 1845, the United States Naval Academy was authorized by Congress to begin awarding a B.S. in 1933. It now offers a four-year curriculum leading to a B.S. in twenty-one majors, among them aerospace engineering, chemistry, computer science, economics, electrical engineering, English, general engineering, general science, history, information technology, mathematics, mechanical engineering, naval architecture, ocean engineering, oceanography, physics, political science, quantitative economics, and systems engineering. Majors in Arabic and Chinese are scheduled to be added with the graduating class of 2010.

The Naval Academy has a student body of roughly 4,000 midshipmen who come from all fifty states, Washington (DC), Puerto Rico, and the Northern Marianas. The 2009 class, for which the latest statistics are available, also includes eleven international students from Guyana, Honduras, Ireland, Malaysia, the Maldives, Mauritius, the Philippines, Singapore, Taiwan, and Thailand. The student body includes roughly 20 percent minorities and 20 percent women. Out of 11,000 applicants, only 1,200 were admitted

$\overline{\text { Brannon Wheeler is the director of the United States Naval Academy's Center for Middle }}$ East and Islamic Studies. The academy is located in Annapolis, Maryland. 
into the class of 2009. Over half of the midshipmen were members of the National Honor Society, and around 90 percent were varsity athletic letter winners in their respective senior high schools. Applicants to the Naval Academy must be nominated by the American president, vice president, a Congress member, or a territorial representative and from other special categories (e.g., the children of Medal of Honor recipients). Since 1976, it has enrolled female students; they now typically comprise about 20 percent of each entering class.

The Naval Academy does not record the religious background of midshipmen, but in addition to the century-old Naval Academy Chapel and the Uriah P. Levy "Jewish Chapel," the Naval Academy has a prayer room for Muslim midshipmen and a number of other religious groups, such as the Buddhist Study Group. Friday prayers, held in the Muslim Prayer Room, are regularly attended by both students and faculty members.

The student body also includes foreign students who are enrolled alongside American students for four years. After graduation, they return to their home countries and are expected to perform some form of national service. Currently, approximately fifty foreign students from almost thirty nations are enrolled. Upon graduation, American students are commissioned as officers, as ensigns in the U.S. Navy, or as second lieutenants in the Marine Corps. Graduates are normally expected to serve as officers for five years or to reimburse the United States for the cost of the education they received.

The Naval Academy's curriculum focuses on academics. Students are required to participate in such professional development courses as physical fitness training, infantry drill, moral reasoning, naval engineering, navigation, strategy and tactics, leadership, warfare systems design, and military justice. During summer "cruises," students spend three to four weeks aboard ships, submarines, and sailboats and have opportunities to gain experience with aviation and other Navy and Marine Corp operations.

The Naval Academy is unique among the other American service academies in that its faculty is roughly half civilian tenured or tenure-track. All civilian faculty members have doctorates in their areas of teaching and research. Military instructors are given temporary multi-year teaching assignments, and permanent military professors are assigned teaching positions until retirement after having earned a Ph.D. as part of their naval service.

During its 160-year history, the Naval Academy has excelled in producing the highest caliber of officers who are ready to assume leadership roles in the Navy and the Marine Corps, government service, and as outstanding private citizens. Graduates include a former president of the United States, cab- 
inet members, ambassadors, Congressmen, state governors, and Nobel Prize winners. The Naval Academy has also graduated 52 astronauts, 43 Rhodes scholars, 15 Marshall scholars, and a number of Olmstead, Fitzgerald, and Burke scholars. It had seven Rhodes scholars during the 2005-06 academic year, more than any other institution in the country.

\section{The Center for Middle East and Islamic Studies (CMEIS)}

Recent geopolitical developments, since $9 / 11$ but beginning with the end of the cold war, emphasize the increasingly vital need for greater knowledge, improved language capacity, and a more global perspective shared across the American government, but especially in the Department of Defense. This perspective was behind the "Defense Language Transformation Roadmap" published by the Office of the U.S. Secretary of Defense in January 2005.

The center's mission is to enhance the students' educational opportunities by supporting international and regional studies, curricular innovation, community outreach and by serving as a resource center on all aspects of Middle East and Islamic studies. As a center for interdisciplinary research and teaching, CMEIS is positioned to develop and lead initiatives in regional knowledge at the Naval Academy and the broader Department of Defense.

No other military academy or war college currently has a regional center comparable to CMEIS, but they do offer courses and areas of study that focus on the Middle East. The Combating Terrorism Center at the U.S. Military Academy at West Point employs faculty members and fellows who research and teach in areas related to Islam and the Middle East. The Naval Post-Graduate School in Monterey offers regional studies in the Middle East leading to an M.A. in national security affairs. The National War College at the National Defense University in Washington, DC, has been developing an Islamic civilization course as part of its curriculum required for an M.A. in security studies. The other war colleges also offer individual courses with a Middle East and Islamic focus as part of their degree programs.

Other research and educational centers within the Department of Defense provide specialized educational programs with a Middle East and Islamic focus. The Near East South Asia Center for Strategic Studies at the National Defense University in Washington, DC, for example, was founded in 2000 to enhance security in those two regions through short-term senior and executive programs in security studies for foreign military and government officials 
from twenty-five nations. The Asia Pacific Center for Strategic Studies in Honolulu, founded in 1995, has similar programs for forty-five Asian-Pacific nations. The Center for Advanced Operational Cultural Learning (CAOCL) at Quantico in Virginia, founded in 2006, is the U.S. Marine Corps' culture and language center designed to promote "a grasp of culture and language as regular, mainstream components of the operating environment."

\section{The Faculty}

The director of CMEIS reports directly to the provost. CMEIS is governed by a steering committee made up of representatives from all four divisions of the Naval Academy and all chairs of the departments within the humanities and social sciences. This includes a representative from the Department of Leadership, Language, and Law, a department that includes a number of philosophers who focus on issues of ethics and religion. But unlike the other departments represented on the steering committee that report to the provost of the Naval Academy, LEL reports to the commandant of midshipmen as part of professional development.

CMEIS faculty members are assigned or share appointments in one of the Naval Academy's regularly established academic departments. For the time being, these are limited to the Division of Humanities and Social Sciences. Faculty members affiliated with CMEIS are elected by current members and approved by the provost on the basis of criteria related to research and teaching on the Middle East and Islamic studies.

Currently, nine full-time faculty members are affiliated with CMEIS: Clarissa Burt, language studies (Arabic language and literature); John Limbert, political science (Iran and the Middle East); Mohamed Rahouma, language studies (Arabic); Sanaa Sadek, language studies (Arabic); Ermin Sinanovic, political science (Southeast Asia and Islam); Ernest Tucker, history (Islamic civilization and history); Brannon Wheeler, director, CMEIS (Islam and the history of religions); and Deborah Wheeler, political science (the contemporary Middle East and Islam). As of August 2007, the number of faculty members is expected to increase to twelve, with the addition of a permanent military professor in modern Middle East history, an additional assistant professor of Arabic, and an academic program coordinator who will work with both CMEIS overseas programs and teach Arabic for the Language Studies Department.

As a whole, these faculty members have served as Senior Fulbright Fellows to Turkey, Kuwait, Jordan, Egypt, and Oman. They have also held fel- 
lowships at the American Center for Oriental Research in Jordan, the American Research Center in Egypt, the Institute for Ismaili Studies, the Oxford Centre for Islamic Studies, the Institute of Turkish Studies, the Royal Institute for Interfaith Studies, and the American Institute of Maghreb Studies.

Some recent faculty publications include John Limbert's Shiraz in the Age of Hafez: The Glory of a Medieval Persian City (University of Washington: 2004), Deborah Wheeler's The Internet in the Middle East: Global Expectations and Local Imaginations in Kuwait (SUNY: 2005), Brannon Wheeler's Mecca and Eden: Ritual, Relics, and Territory in Islam (University of Chicago Press: 2006), and Ernest Tucker's Nadir Shah's Quest for Legitimacy in Post-Safavid Iran (University Press of Florida: 2006).

In addition to the faculty, CMEIS is also governed in part by the Student Association for Middle East and Islamic Studies. Currently, this association includes roughly thirty students and is governed by a president and a secretary, both of whom are elected by current student members from a pool of eligible juniors.

\section{The Kylan Jones-Huffman Memorial Lecture Series}

This lecture series is named after Navy Lieutenant Kylan Jones-Huffman, who was killed on 21 August 2003 by unidentified gunfire while on temporary assignment as an intelligence officer with the 1st Marine Expeditionary Force in Hilla, Iraq. He had been briefing incoming civil affairs personnel trying to set up a government in the southern part of the country. LT JonesHuffman graduated with honors in history from the Naval Academy in 1995 and earned an M.A. at the University of Maryland before returning to the Naval Academy in 1999 to teach a course on ancient Greek and Roman history. He had been accepted into a Ph.D. program at Georgetown University and was just ten days short of returning home to begin when he was killed.

The objective of this lecture series is to bring a wide variety of diverse perspectives to the Naval Academy's students and faculty members and the surrounding community. The different views offered by these speakers equip students and faculty members with resources and insights they would not normally receive during their regular course of study. In the past two years, a number of prominent scholars, artists, current and former government officials and military officers from the United States and other nations have participated. Among them have been HRH Prince El Hassan bin Talal of Jordan; Rashid Khalidi, Edward Said Professor of Arab Studies, Columbia 
University; Bruce Lawrence, professor and director, Duke Islamic Studies Center; Ahmed Mustafa, artist, Prince of Wales Institute of Architecture; Carol Delaney, professor of anthropology, Stanford University; Rahim Alhaj, musician, classical Iraqi makam; Ingrid Mattson, president of the Islamic Society of North America; Mahdi Tourage, professor of Islamic Studies, Colgate University; and Nathaniel Fick, author of One Bullet Away: The Making of a Marine Officer (Houghton Mifflin: 2005).

In addition to this public lecture, each guest is invited to attend classes over the course of one or two days, to meet with faculty members and students, and to learn more about the Naval Academy and how CMEIS initiatives are working to increase academic focus on regional and languages studies across the curriculum.

CMEIS also sponsors a yearly Brown-bag Study Group that attracts both civilian and military faculty and staff members from all parts of the Naval Academy. Last year, the study group read Abdulaziz Sachedina's The Islamic Roots of Democratic Pluralism (Oxford: 2001) and Michael Cook's Forbidding Wrong in Islam (Cambridge: 2003). Both professors came to the Naval Academy and discussed their works with a small group of faculty members, attended classes, and had the chance to meet and talk with students in informal settings. Next year, the group is scheduled to read Richard Bulliet's The Case for Islamo-Christian Civilization (Columbia: 2003).

On a regular (almost weekly) basis, CMEIS supports the visits of other scholars, officials, and officers to the Naval Academy in areas related to the Middle East and Islamic studies. For example, it has sponsored visits from the U.S. Department of State's Bureau of Near East Affairs, the office of the U.S. Assistant Secretary of Defense for International Affairs, various military and civilian intelligence and analyst organizations, former and current foreign area officers from the Middle East and Southeast Asia, Navy and Marine Corps officers and enlisted personnel returning from service in the Middle East, and directors of other educational programs having a Middle East and Islamic studies focus.

Due to its close proximity to Washington, DC, the Naval Academy regularly receives official visits from foreign military and civilian delegations. Some of these are part of an official program through the U.S. Navy's chief naval officer; others are initiated through the Department of State's Distinguished Visitor Program and similar outreach efforts. CMEIS works to have these delegations attend classes, meet with faculty members and students, and learn more about opportunities for cooperation and coordination with CMEIS in regional and language studies. In the past year, this has included 
group visits from Afghanistan, Iraq, Bahrain, Israel, Egypt, Saudi Arabia, Tonga, and Oman.

\section{Curriculum Development}

CMEIS serves as a resource center and advises the Naval Academy's administration and faculty members on curriculum development as it relates to the Middle East and other regions connected with Islamic studies. In addition to the two new majors in Arabic and Chinese, the Naval Academy is considering the possibility of introducing interdisciplinary regional studies majors. The director and affiliated faculty members of CMEIS regularly review different interdisciplinary programs related to the study of the Middle East and Islam in North America, Europe, Asia, and the Middle East.

This review provides useful models for the ongoing development of regional studies at the Naval Academy, as well as connections for exchange and institutional cooperation. In the past few years, CMEIS has initiated discussions with programs in Canada, Bosnia-Herzegovina, Jordan, Indonesia, Russia, Oman, Israel, the United Kingdom, Egypt, Singapore, and Pakistan. These connections allow the Naval Academy's programs to expand into international faculty exchanges, sabbatical opportunities, joint research projects, and sharing ideas related to all aspects of academic research and teaching on the Middle East and Islam.

CMEIS offers additional resources to the Naval Academy's faculty members through its sponsorship of faculty workshops that bring together roughly twenty faculty members from across the curriculum to discuss issues of pedagogy as they relate to interdisciplinary regional and language study. During the past two years, workshops have focused on gender, Arabic and Islamic literature, Islamic studies, religious studies, Islamic law, and tolerance and pluralism in Islam. These workshops, which are initiated by faculty interest within departments and by faculty members affiliated with CMEIS, help to support the creation of new courses and pedagogical innovation within existing curricular offerings.

As CMEIS grows with additional external support, the funding of curricular development initiatives is essential. Currently, the Naval Academy offers faculty members the opportunity to apply for curricular development funds in order to enhance core course offerings. CMEIS is to supplement this funding to support specifically the creation of new courses in the area of Middle East and Islamic studies, and to encourage the augmentation of existing core courses to include a more extensive integration of regional studies. The goal 
is to increase the attention given to regional specific issues as they arise in the course of larger pedagogical frameworks, such as international relations, western civilization, economic systems, and comparative literature.

With CMEIS support, faculty members can apply to develop new course materials through research, international travel, and coordination with partner institutions. Some examples of this include sending non-specialists who teach core courses in political science or history on brief two-week culturalimmersion trips to the Middle East, and funding specialists who want to attend international conferences and visit archives in the region. To date, faculty members have traveled to Oman, Indonesia, Turkey, the United Kingdom, Jordan, Hungary, Greece, Malta, Israel, and Singapore, among other locations.

Support of these programs gives them the capacity to enhance their teaching by providing their students with fresh materials, the latest research, and firsthand experience with disciplinary issues from broad international and interdisciplinary perspectives.

\section{Semester and Language-Immersion \\ Study Abroad Programs}

By law, the Naval Academy is allowed to accept up to twenty-four students from foreign military academies in exchange for its own students, who will receive instruction at those foreign academies. Since 2005, it has had exchange programs with the Royal Military College of Canada, the Escuela Naval Almirante Padilla in Columbia, the Ecole Navale in France, the Japan National Defense Academy, and the Escuela Naval Militar in Spain.

Beginning in the fall of 2007, the Naval Academy will send students for a semester abroad at civilian universities in Jordan, Egypt, Singapore, and China. Other options in Kuwait, Yemen, Israel, and Morocco are being examined for future years. Students are expected to devote a significant portion of their time abroad to regional and language studies, but also to continue working toward their general and major graduate requirements. Unlike many other colleges and universities, the Naval Academy is mandated by law to graduate its students within four years. This requirement puts relatively heavy restrictions on which students are eligible for study abroad, especially as regards those majoring in engineering, science, naval architecture, and other technical majors.

Through its International Programs Office and the Department of Language Studies, the Naval Academy offers language immersion programs 
for Chinese, Arabic, German, French, Japanese, Russian, and Spanish. During the summer of 2005, over 100 students visited thirteen different countries through these various programs. Arabic language immersion currently takes place in Egypt, and future opportunities are being explored in Jordan, Kuwait, Tunisia, Morocco, and Yemen.

CMEIS encourages and coordinates student travel and cultural immersion through other programs. With support from the Olmstead Foundation and other groups, CMEIS faculty members have planned student trips to Saudi Arabia, Israel, Turkey, and other parts of the Middle East and Asia. CMEIS enables students to attend international conferences and accompany faculty members to domestic and international conferences related to the Middle East and Islamic studies. Recently, they have participated in conferences held in Jordan, Finland, Turkey, the United Kingdom, and Kazakhstan.

\section{Outreach}

As part of its mission, CMEIS is involved in both official and non-official outreach programs focused on the Middle East and Islam. In 2006 and 2007, faculty members contributed to international military conferences in Turkey and Greece on regional security and arms control in the Middle East. CMEIS faculty members meet on a regular basis with naval and other foreign military attachés in Washington, DC, from the Middle East and Muslim countries. During the past two years, CMEIS has brought faculty members and students to a formal iftar hosted by the commandant of the Marine Corps for all military attachés from Muslim countries with embassies in Washington, DC. CMEIS faculty members also attended a related program sponsored by the Marine Corps coinciding with the Islamic New Year.

CMEIS encourages faculty participation in and contributions to other Department of Defense activities both to gain a better understanding of military missions and to improve their capabilities in the classroom. This includes CMEIS faculty members providing lectures and consultation for Central Command, Pacific Command, the Marine Corps Headquarters, and the Pentagon. CMEIS faculty members act as advisors to graduate-level military education at the various war colleges and intelligence colleges, and also work with the Marine Corps and Navy Foreign Area Officer programs. For example, they served as advisors to the Marine Corps Mojave Viper exercises at 29 Palms in California and have contributed to the Regional Security Education Program, in which expert instructors offer seminars aboard naval vessels deploying to Asia and the Middle East. 
On the international level, CMEIS acts as a liaison between the Naval Academy and foreign navies and other military and civilian educational institutions in the Middle East and Asia. In the past few years, this has included meeting with officers and officials from Oman, Jordan, Israel, Singapore, Egypt, Bahrain, Saudi Arabia, the United Arab Emirates, Indonesia, Kuwait, and Yemen. These meetings provide the opportunity to promote understanding and cooperation between the Naval Academy and foreign militaries and governments. They also help to provide future opportunities for the Naval Academy's students to live with and learn from the people of the Middle East and Asia.

\section{Future Developments}

CMEIS continues to push for more opportunities for students and faculty members to acquire firsthand experience with the cultures, history, and politics of the Middle East and Islamic world more broadly. Future initiatives include teaching and research fellowships both in and out of residence at the Naval Academy; military academy exchanges in the Middle East and Asia; joint faculty research projects with institutions in the Middle East, Africa, and Asia; and increased participation from regional militaries in Naval Academy programs.

Ultimately, the educational goals of CMEIS are intended to foster not only mutual understanding, but also an environment in which American and foreign officers can work together to build a more inclusive and generous context within which we can work toward lasting ties of friendship. 